\title{
MECHANICAL PROPERTIES OF HEAVY WEIGHT CONCRETE USING HEAVY WEIGHT COARSE-AGGREGATE AS HEMATITE (Fe58 HIGH GRADE IRON ORE)
}

\author{
B. Sagar Singh ${ }^{1}$, K.V.Ramana ${ }^{2}$ \\ ${ }^{I}$ M.Tech Student, Civil Department, G.Pulla Reddy Engineering College, Andhra Pradesh, India \\ ${ }^{2}$ Asst Prof., Civil Department, G.Pulla Reddy Engineering College, Andhra Pradesh, India
}

\begin{abstract}
Density concrete is commonly used for radiation shielding of nuclear-reactors and other structures like counter weights, coating of off-shore pipelines. Density concrete or heavy weight concrete is designed by using heavy weight aggregates such as hematite, magnetite, barite etc. The material is called hematite is used in this special concrete.

Integral part of this paper is replacing coarse-aggregate by hematite aggregate partially from 0 to $50 \%$ volume at $25 \%$ intervals. The concrete mix as per IS-10262-(2009) is used for M25 and M35 grades of concrete and in this only coarse aggregate is replaced with heavy weight hematite coarse aggregate and natural sand is used as fine aggregate and three levels of silica fume at $5 \%, 10 \%$ and $15 \%$ are used by weight of cement. All mixes are designed for 100mm slump. Water-cement ratio as per grade of concrete
\end{abstract}

Keywords: Density Concrete, Hematite, Heavy Weight Aggregate, Compressive Strength, Silica Fume

\section{1INTRODUCTION}

The main aim of this paper is to find a suitable local substitute for the high density iron ore. Heavy weight ironore is used as the main ingredient of the high density concrete mix for concrete coating of sub-merged marine pipelines which is transportation of petroleum materials like importing crude oil and domestic gas, desired heavyweight concrete is usually used for radiation shielding, counter weights. Radiation shielding is generally used in nuclear power plants to protect against radioactive rays. High density concrete observes neutrons which are accurate construction material which protects from irradiated rays and causing harmful effects to environment and living things, another important aspect is resistant against freeze and thawing cycles and weathering effects. It acts as anti corrosion while used as reinforcing wire-mesh is wrapped and incorporated in the concrete, especially for oil pipe lines.

High density concrete or heavy weight concrete is concrete should have density greater than $2600 \mathrm{~kg} / \mathrm{m} 3$. High density concrete can be made from natural heavy weight aggregates are commonly used having specific gravity ranging from barites (2.5 - 3.5), magnetite (3.5 - 4.0) and hematite (4.0 $4.5)$ occasionally. Through previous research we can also be made using iron as a replacement for the portion of either coarse aggregate or fine aggregate, these give even greater densities of $5900 \mathrm{~kg} / \mathrm{m} 3$ for iron.

Heavy weight or high density concrete can be designed in same way as normal weight concretes, but the additional self weight should be taken into account. These can be transported and placed in the same way as normal weight concretes but the additional density means that smaller volumes can be transported and placed.

\subsection{Geological Deposits}

Hematite deposits in Kurnool district of Andhra Pradesh state are found in the form of associated with rocks of dharwar sediments or purana formations. However low grade iron ore are also known from upper gondwana laterite capping on Deccan traps as per both hematite and magnetite deposits occur in the state. These sedimentary deposits of hematite are found in Kurnool district in veldurti, ramallakota. In this present study hematite of ramallakota is used in concrete.

\subsection{Experimental and Field Study}

The aim of present work to study the mechanical properties in field of civil engineering works in which hematite is used as coarse aggregate in heavy weight concrete which is used for offshore pipe lines and applicable where ever necessary in field of nuclear research, hospitals, scientific research and radiation shielding etc.

\section{MATERIALS AND METHODS OF MIX DESIGN}

The key ingredients of concrete used in this study i.e. cement ,fine aggregate, coarse aggregate as well as hematite coarse aggregate of size $20 \mathrm{~mm}$ and $10 \mathrm{~mm}$ are tested before use in trial mix of concrete. The relevant tests for material concern as per IS 456: 2000 i.e. Indian standard plain and reinforced concrete code of practice. 


\subsection{Cement}

The cement used in this experimental work is 53 grade ordinary Portland cement. Its properties are tested as per IS 122691987 as shown in table 1

Table -1: Properties of cement:

\begin{tabular}{|l|l|l|}
\hline S.no & Description of test & Results \\
\hline $\mathbf{1}$ & Fineness of cement & $3.12 \%$ \\
\hline $\mathbf{2}$ & Specific gravity of cement & 3.11 \\
\hline $\mathbf{3}$ & Standard consistency & $31 \%$ \\
\hline $\mathbf{4}$ & Initial setting time & $160 \mathrm{~min}$ \\
\hline $\mathbf{5}$ & Final setting time & $250 \mathrm{~min}$ \\
\hline $\mathbf{6}$ & 28days Compressive strength & $65 \mathrm{~N} / \mathrm{mm}^{2}$ \\
\hline
\end{tabular}

\subsection{Aggregates}

Fine aggregate i.e. natural sand from Tungabhadra river is used. Must do tests such as specific gravity, water absorption and sieve analysis, etc. have been done as per Indian Standard. The crushed well graded angular shaped of size $20 \mathrm{~mm}$ as per IS $383-1970$ is used as coarse aggregate.(F.A means fine aggregate and C.A means coarse aggregate) and all the laboratory test of aggregates with respect to material like bulk density, specific gravity, flakiness index, water absorption, crushing test and impact test are conducted

Table -2: Physical properties of F.A and C.A

\begin{tabular}{|l|l|l|l|}
\hline S no & Properties & $\begin{array}{l}\text { River sand } \\
\text { (F.A) }\end{array}$ & C.A \\
\hline 1 & Particle shape & Rounded & Angular \\
\hline 2 & Particle size & $4.75 \mathrm{~mm}$ & $20 \mathrm{~mm}$ \\
\hline 3 & Specific gravity & 2.68 & 2.67 \\
\hline 4 & Silt content & $8.1 \%$ & Nil \\
\hline 5 & Water absorption & 2.45 & 2.25 \\
\hline 6 & Fineness modulus & 2.81 & 4.606 \\
\hline
\end{tabular}

Table -3: Sieve analysis of Fine aggregate

\begin{tabular}{|l|l|l|l|l|l|}
\hline $\begin{array}{l}\text { S } \\
\mathbf{n} \\
\mathbf{o}\end{array}$ & $\begin{array}{l}\text { Sieve } \\
\text { size } \\
\text { in } \mathbf{~ m m}\end{array}$ & $\begin{array}{l}\text { Weight } \\
\text { retained } \\
\text { in gm }\end{array}$ & $\begin{array}{l}\text { \% } \\
\text { weight } \\
\text { retaine } \\
\text { d }\end{array}$ & $\begin{array}{l}\text { Cumulat } \\
\text { ive \% } \\
\text { weight } \\
\text { retained }\end{array}$ & $\begin{array}{l}\text { \% } \\
\text { passi } \\
\text { ng }\end{array}$ \\
\hline $\mathbf{1}$ & 4.75 & 25 & 2.5 & 0.25 & 99.75 \\
\hline $\mathbf{2}$ & 2.36 & 20 & 2 & 2.25 & 97.75 \\
\hline $\mathbf{3}$ & 1.18 & 130 & 13 & 15.25 & 84.75 \\
\hline $\mathbf{4}$ & 600 & 570 & 57 & 72.25 & 27.75 \\
\hline $\mathbf{5}$ & 350 & 225 & 22.5 & 94.75 & 5.25 \\
\hline $\mathbf{6}$ & 150 & 15 & 1.5 & 96.25 & 3.75 \\
\hline $\mathbf{7}$ & PAN & 15 & 1.5 & & 100 \\
\hline & & 1000 & & 281 & \\
\hline
\end{tabular}

Fineness modulus $=\quad \sum \mathrm{F} / 100=2.81$

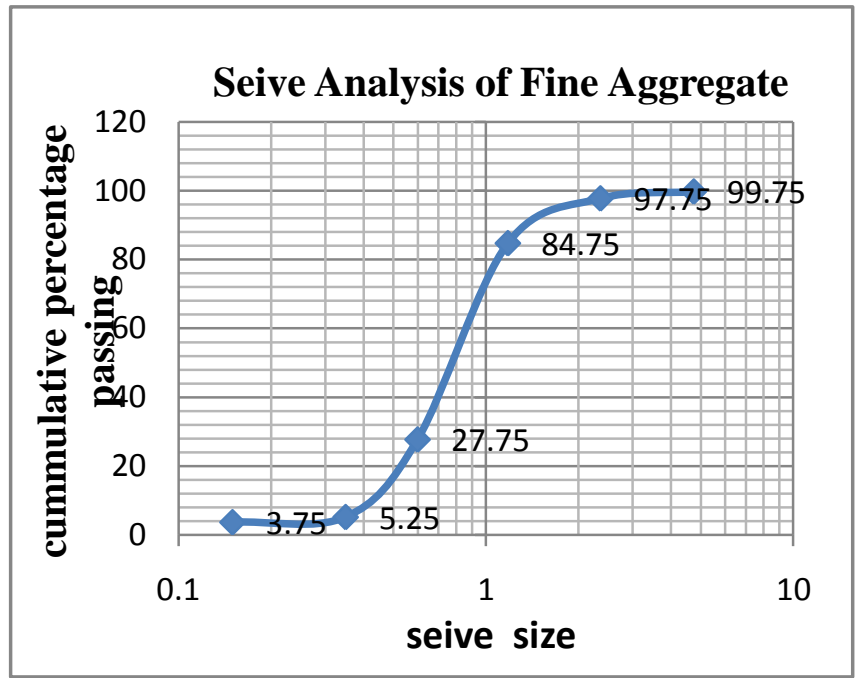

Chart -1: sieve analysis of fine aggregate

Table -4: Sieve analysis of coarse aggregates

\begin{tabular}{|l|l|l|l|l|l|}
\hline $\begin{array}{l}\text { Sn } \\
\text { o }\end{array}$ & $\begin{array}{l}\text { Siev } \\
\text { ( } \\
\text { size } \\
\text { in } \\
\text { mm }\end{array}$ & $\begin{array}{l}\text { Weight } \\
\text { retaine } \\
\text { d }\end{array}$ & $\begin{array}{l}\text { \% } \\
\text { weight } \\
\text { retaine } \\
\text { d }\end{array}$ & $\begin{array}{l}\text { Cumulativ } \\
\text { e weight } \\
\text { retained (f) }\end{array}$ & $\begin{array}{l}\text { \% } \\
\text { passin } \\
\text { g } \\
(\mathbf{1 0 0 - f )}\end{array}$ \\
\hline 1 & 80 & 0 & 0 & 0 & 100 \\
\hline 2 & 63 & 0 & 0 & 0 & 100 \\
\hline 3 & 50 & 0 & 0 & 0 & 100 \\
\hline 4 & 40 & 0 & 0 & 0 & 100 \\
\hline 5 & 31.5 & 30 & 0.3 & 0.2 & 99.8 \\
\hline 6 & 25 & 1120 & 11.2 & 11.5 & 88.5 \\
\hline 7 & 20 & 4170 & 41.7 & 53.2 & 46.8 \\
\hline 8 & 12.5 & 4360 & 43.6 & 96.8 & 3.2 \\
\hline 9 & 10 & 220 & 2.2 & 99 & 1 \\
\hline 10 & 6.3 & 90 & 0.9 & 99.9 & 0.1 \\
\hline 11 & 4.75 & 10 & 0.1 & 100 & 0 \\
\hline & & & & 460.6 & \\
\hline
\end{tabular}

Fineness modulus $=\sum \mathrm{F} / 100 \quad=4.606$

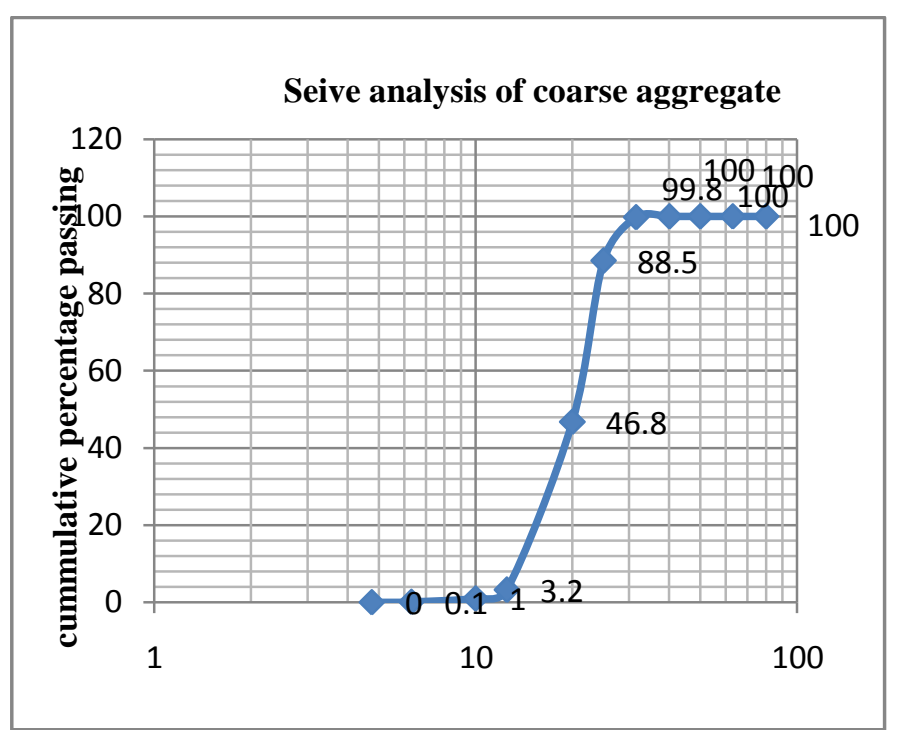

Chart -2: sieve analysis of coarse aggregate 


\subsection{Water}

Portable laboratory tap water was used for concrete mix. In addition water should be Clean and free from oils, acids, leaves, organic matters etc are must taken precautions.

\subsection{Hematite Coarse Aggregate}

Complete 7 samples for knowing the specific gravity of hematite aggregate which was found above 4.0 i.e. my result of sample is specific gravity $4.3 .20 \mathrm{~mm}$ and $10 \mathrm{~mm}$ used as coarse aggregate.

Table -5: Physical properties of hematite

\begin{tabular}{|l|l|l|}
\hline S no & Properties & Results \\
\hline $\mathbf{1}$ & specific gravity & 4.3 \\
\hline $\mathbf{2}$ & Bulk density & $2300 \mathrm{~kg} / \mathrm{m}^{3}$ \\
\hline $\mathbf{3}$ & Particle shape & ANGULAR \\
\hline $\mathbf{4}$ & Particle size & $20 \mathrm{~mm}^{\text {used }}{ }^{*}$ \\
\hline $\mathbf{5}$ & Color & Reddish \\
\hline $\mathbf{6}$ & Water absorption & $3 \%$ \\
\hline $\mathbf{7}$ & Crushing value & 12.55 \\
\hline $\mathbf{8}$ & Impact value & 12.41 \\
\hline
\end{tabular}

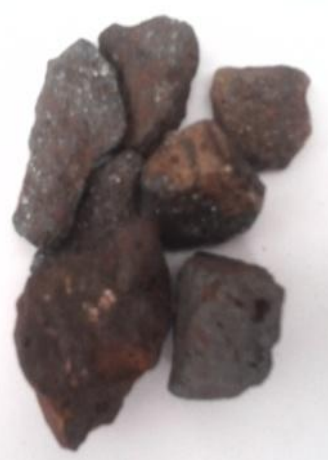

Fig -1: hematite aggregate

Table -6: Chemical composition of normal hematite in

\begin{tabular}{|l|l|}
\hline \multicolumn{2}{|c|}{ weight \% } \\
\hline $\mathbf{F e}_{2} \mathbf{O}_{3}$ & Percentage \% \\
\hline $\mathrm{MnO}$ & 83.16 \\
\hline $\mathrm{MgO}$ & 0.13 \\
\hline $\mathrm{TiO}_{2}$ & 1.56 \\
\hline $\mathrm{Al}_{2} \mathbf{O}_{\mathbf{3}}$ & 0.04 \\
\hline $\mathbf{C a O}$ & 0.60 \\
\hline $\mathbf{S i O}$ & 4.81 \\
\hline $\mathbf{L O I}$ & 4.23 \\
\hline & 0.31 \\
\hline
\end{tabular}

\section{MIXING, CASTING AND CURING}

Mixing was carried out in 100literrs revolving peddle pan mixer. The concrete was cast into steel moulds using a minimal amount of Greece and compacted using a vibrating table. The specimens were demoded after 24 hours and water curing for 28 days.

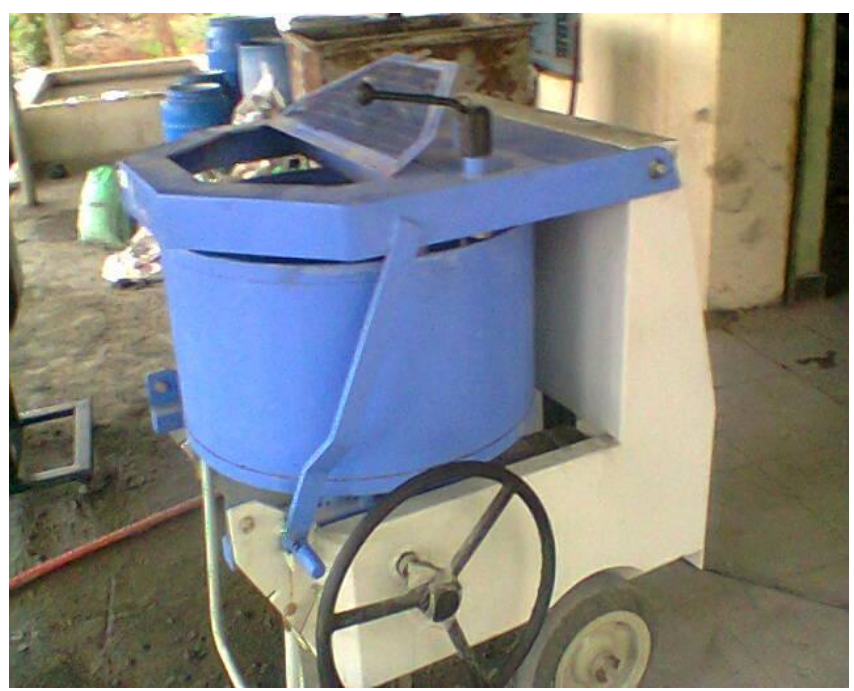

Fig -2: pan mixer

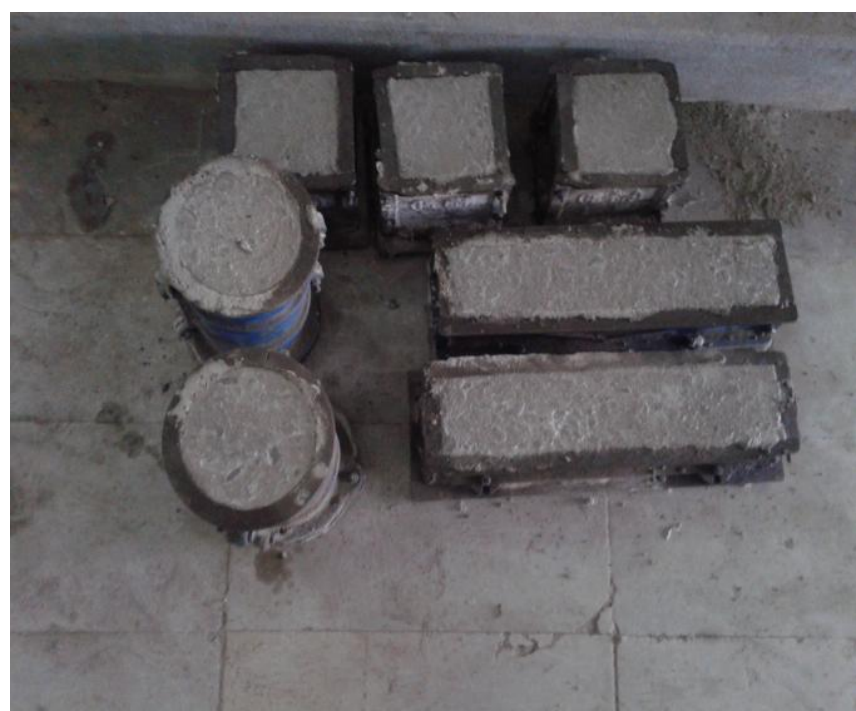

Fig -3: casting of specimens, (cubes, cylinders and beams)

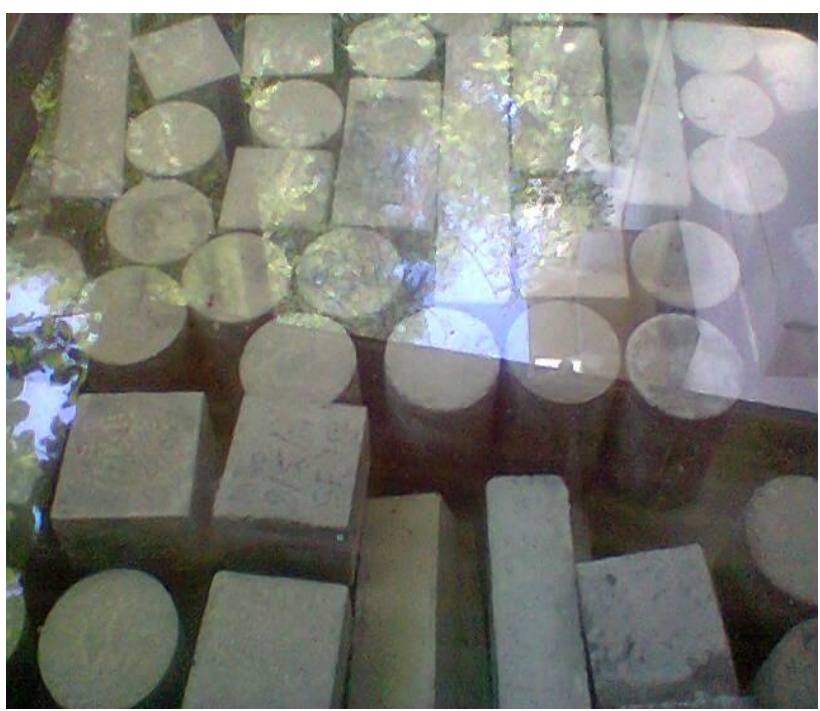

Fig 4: specimen curing tank 


\section{RESULTS AND DISCUSSION}

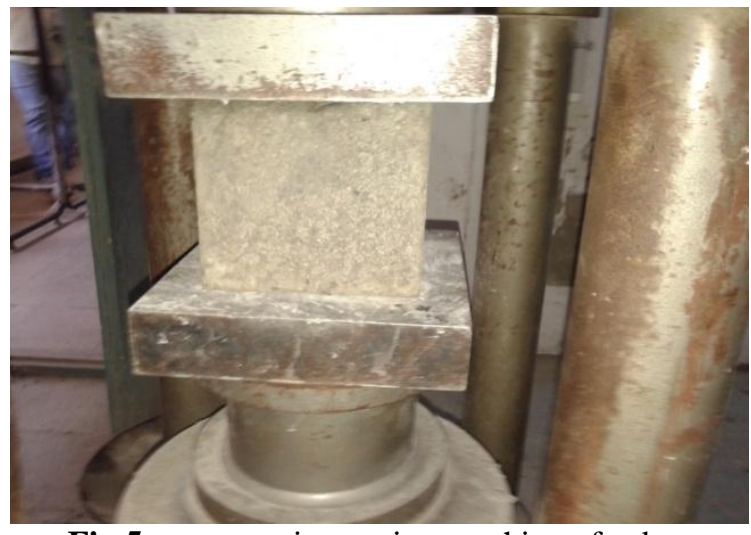

Fig 5: compressive testing machine of cubes

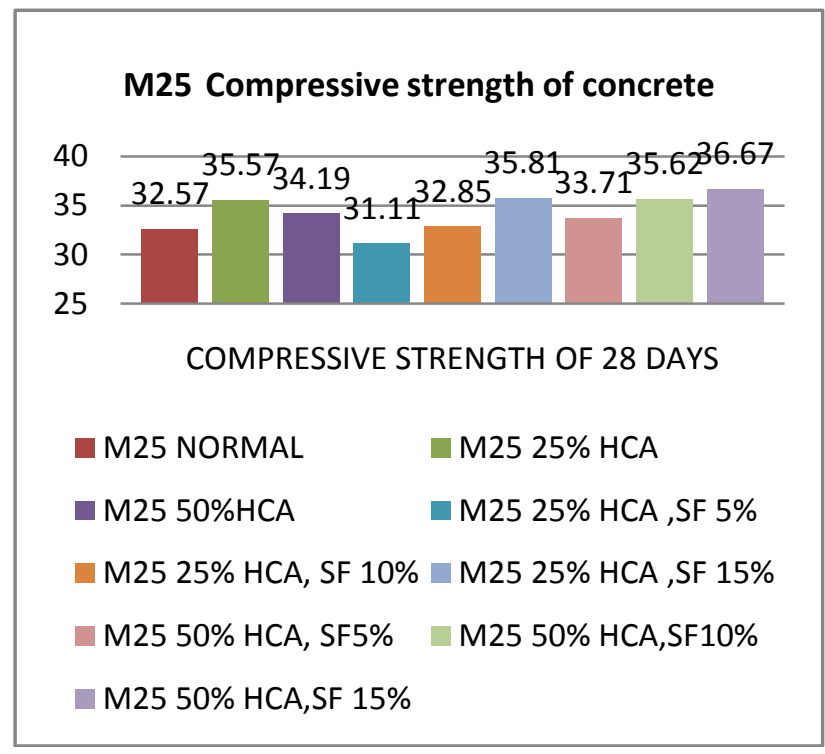

Chart -3: M25 grade of compressive strength of concrete

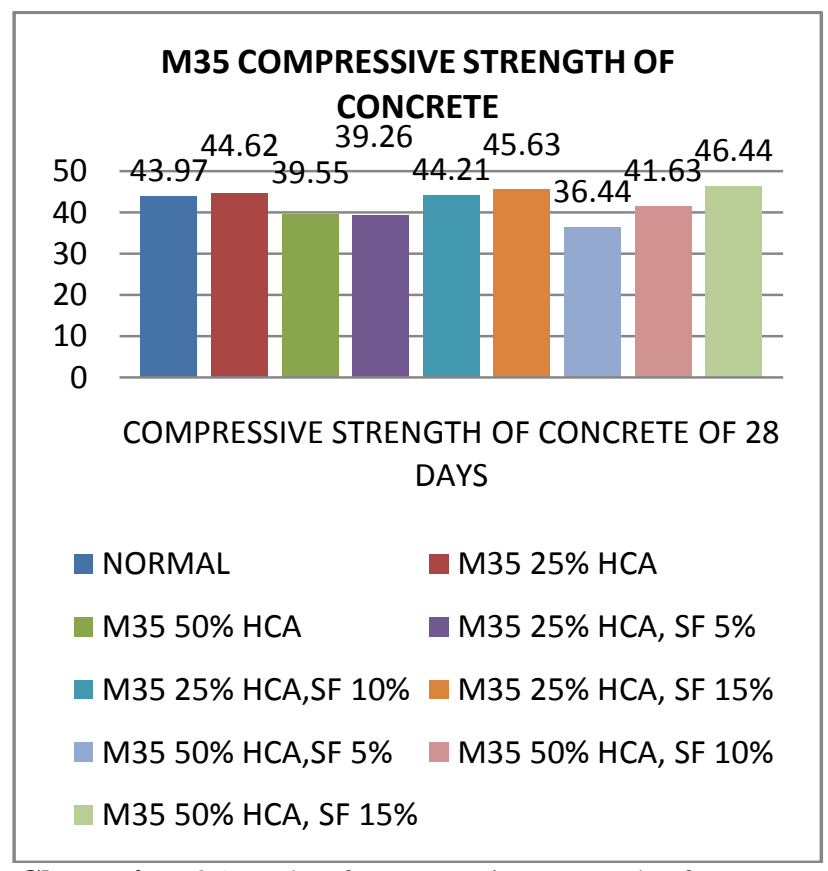

Chart -4: M35 grade of compressive strength of concrete

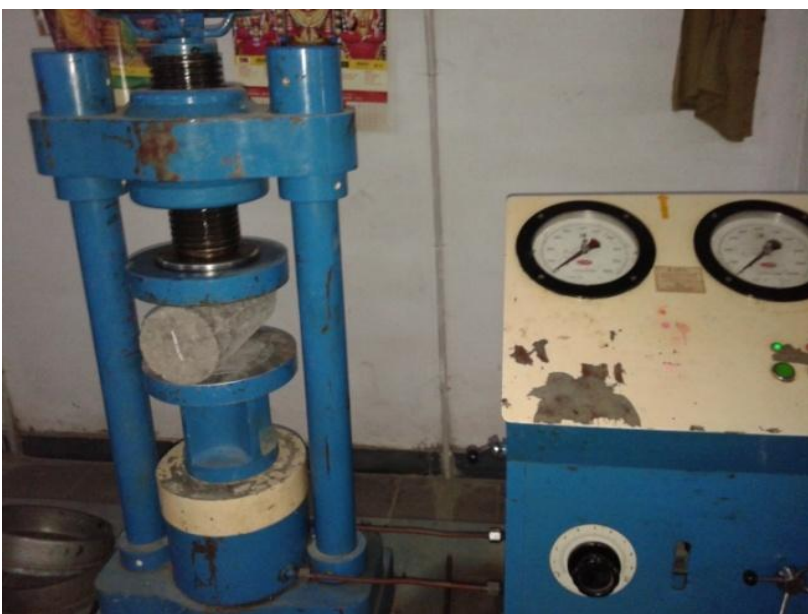

Fig 6: compressive testing machine, split tensile test for cylinders

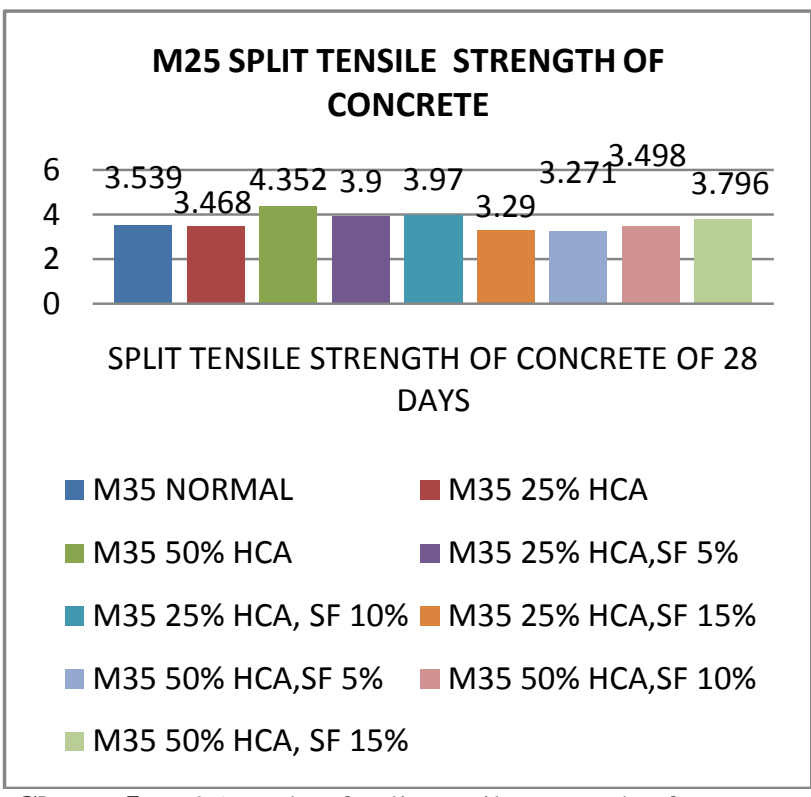

Chart -5: M25 grade of split tensile strength of concrete

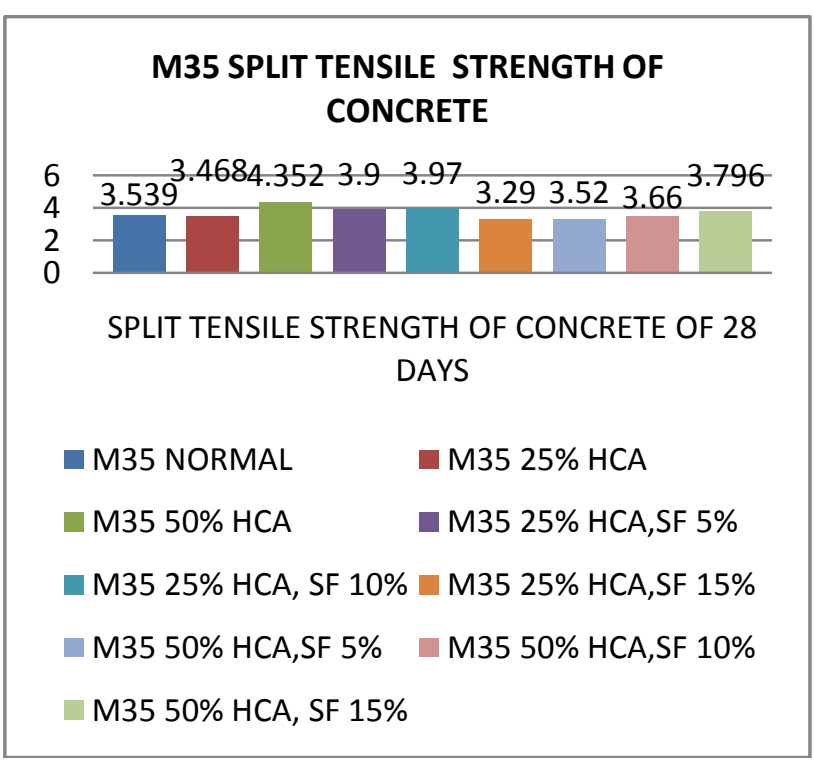

Chart -6: M25 grade of split tensile strength of concrete 


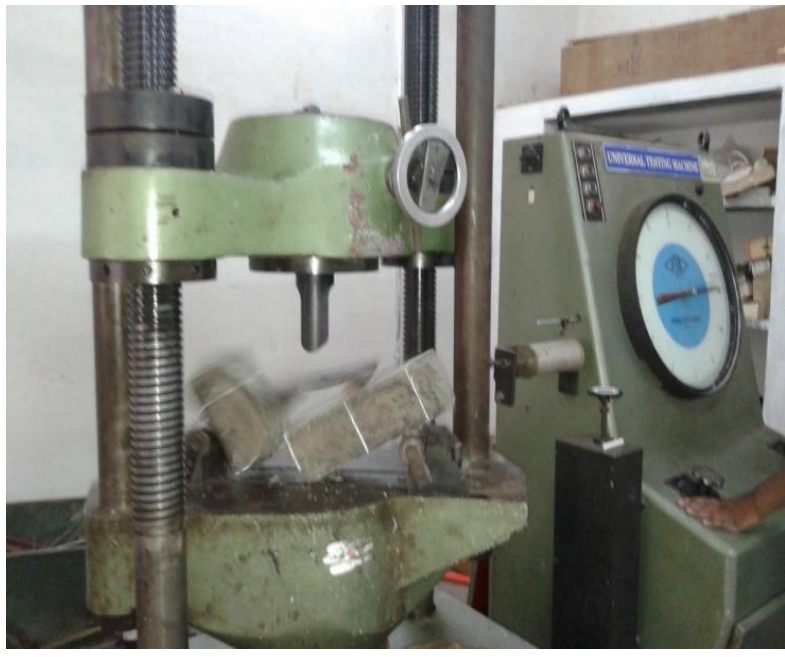

Fig 7: universal testing machine for beams

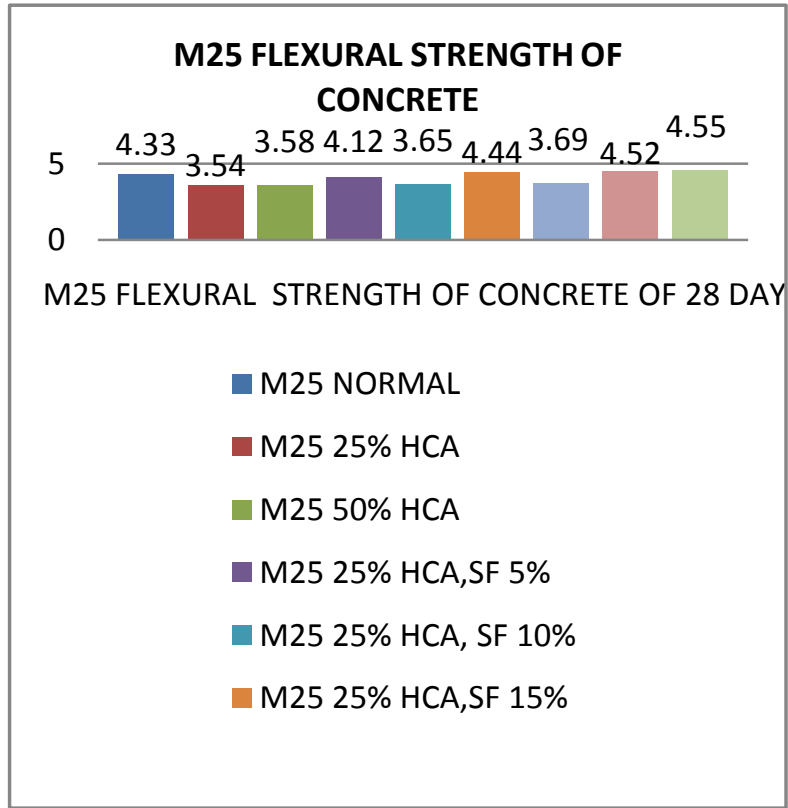

Chart -7: M25 grade of flexural strength of concrete

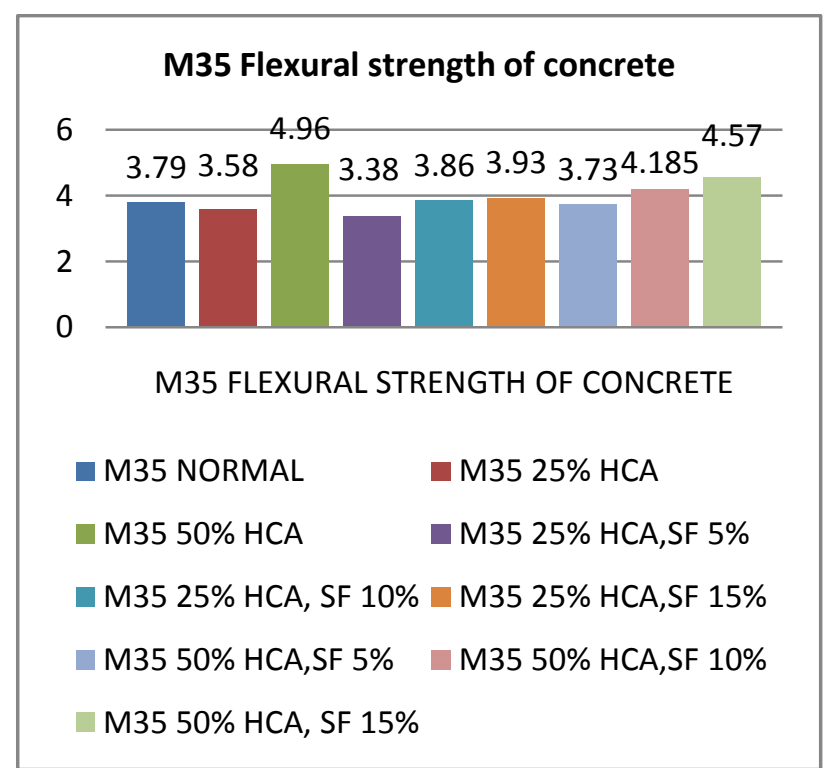

Chart -8: M35 grade of flexural strength of concrete

\section{DENSITY OF CONCRETE}

The increase in percentage of HCA increases the density of concrete. In other words the density is proportional to percentage of HCA. The details are shown in fig where NA represents the concrete made with conventional material, HB represents sample of concrete prepared with HCA replacing $25 \%$ coarse aggregate. And $\mathrm{HC}$ represents sample of concrete prepared with HCA replacing 50\% coarse aggregate. Thus maximum random density is selected for this chart.

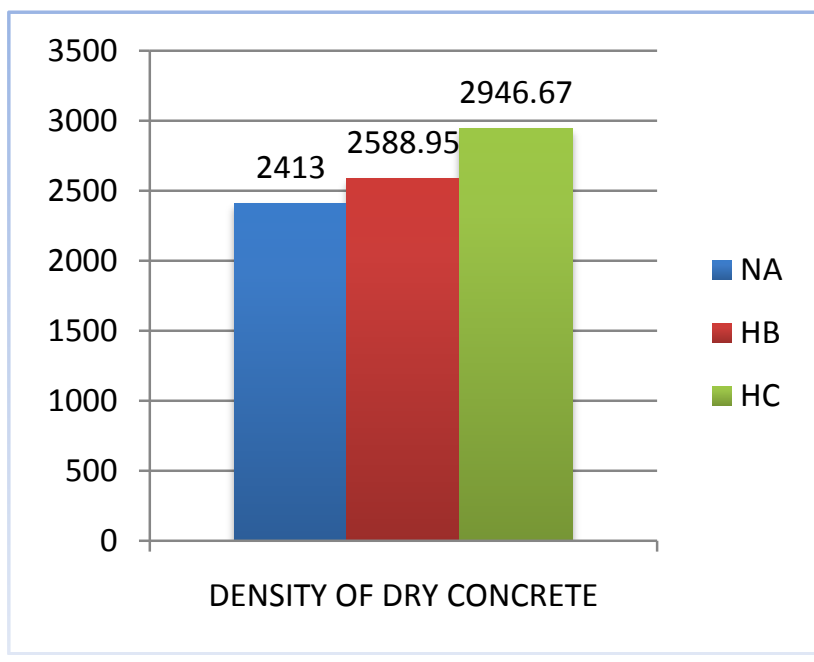

Chart -9: density of dry concrete

\section{CONCLUSIONS}

The primary objective of this study was to evaluate the use of hematite fe-58 high grade iron ore material in the concrete to make it heavy weight or density material, as partially replacement of coarse aggregate. Based on the results obtained in this study, it may be seen that HCA could be used for making heavy weight concrete, without affecting much the compressive strength, tensile strength, flexural strength of concrete.

\section{REFERENCES}

[1]. M A W Gaber: utilization of Um bogma ferro manganese ore as a heavy weight in concrete coating for subsea petroleum pipeline Inventi impact: civil engineering vol. 2013, issue 1

[2]. S P jadhao,M. G shaikh: design development of high strength heavyweight concrete using SBR International journal of scientific \& engineering research volume 4, Issue 5 , may $=2013$

[3]. YUKSEL ESEN and BERIVAN YILMAZER: An investigation of $\mathrm{X}$-ray and radio isotope energy absorption of heavyweight concretes containing barite. Bull master Sci., vol. 1, February 2011, pp. $169-175$.

[4]. Osman gencel, wit old brostow, cengiz ozel, mumin filiz: concrete containing hematite for use as shielding barriers. ISSN 1392-1320 MATERIAL SCIENCE (MEDZIAGOTYRA). Vol 16. No. 3.. Vol 16. No. 3. 2010 
[5]. C. basyigit: The physical and mechanical properties of heavyweight concretes used in radiation shielding. Journal of applied sciences 6 (4): 762 - 766, 2006

[6]. Akkurt, c. basyigit, s. kilincarslan, b.mavi: radiation shielding of concretes containing different aggregates www.elsevier.com cement and concrete research 28 (2006) $153-157$.

[7]. IIker Bekir Topcu: properties of heavyweight concrete produced with barite. Cement and concrete research 33 (2003) $815-822$.

[8]. M.mahdy, p.r.s speare, a.h abdel-reheem: shielding properties of heavyweight, high strength concrete $2^{\text {nd }}$ material specialty conference of the Canadian society for civil engineering.

\section{BIOGRAPHIES}

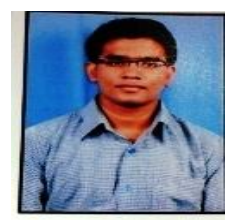

B.SAGAR SINGH pursuing masters degree in $G$ pulla reddy engineering college (autonomous) in Kurnool. Department of civil engineering of course structural engineering. He has interest in construction materials of structures $\mathbf{G}$

Pulla Reddy Engineering College(Autonomous), known as GPREC, is an ISO 9001 - 2000 certified institution and the oldest engineering college of Kurnool, situated in Andhra Pradesh, India. It is an autonomous institute founded by philanthropist and entrepreneur G. Pulla Reddy on 22 February 1985 and is affiliated to JAWAHARLAL NEHRU TECHNOLOGICAL UNIVERSITY, Anantapur. It is approved by All India Council of Technical Education, New Delhi and accredited by National Assessment and Accreditation Council (NAAC) of UGC.

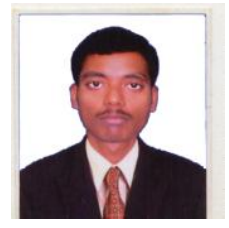

K.V.RAMANA obtained his Master's degree from university college of Engineering JNTUK, Kakinada in 2011. $\mathrm{He}$ worked as a Lecturer in University college of Engineering, Kakinada for 2 years. Later he joined as an ASSISTANT PROFESSOR in G. Pulla Reddy Engineering College, Kurnool and continues now. He Participated and Published papers in both National and International Conferences. He has interest on Rehabilitation and Retrofitting of structures and structural dynamics. He applied Research Projects under SEED division in DST and UGC also. 